\title{
Tecnura
}

\section{Simulation of the styrene production process via catalytic dehydrogenation of ethylbenzene using CHEMCAD ${ }^{\circledR}$ process simulator}

\section{Simulación del proceso de producción del estireno mediante la deshidrogenación catalítica del etilbenceno utilizando el simulador CHEMCAD $^{\circledR}$}

\author{
Amaury Pérez Sánchez ${ }^{1}$ Eddy Javier Pérez Sánchez², Rutdali María Segura Silva ${ }^{3}$
}

Fecha de recepción: 22 de enero de 2017

Fecha de aceptación: 28 de abril de 2017

\begin{abstract}
Cómo citar: Pérez, A., Pérez, E. y Segura, R. (2017). Simulation of the Styrene Production Process Via Catalytic Dehydrogenation Of Ethylbenzene Using CHEMCAD ${ }^{\circledR}$ Process Simulator. Revista Tecnura, 21(53), 15-31. doi: $10.14483 / 22487638.11499$
\end{abstract}

\begin{abstract}
Background: Process simulation has been extensively used in recent years to design, evaluate or optimize processes, systems and specific operations of the chemical industry and its related disciplines. $\mathrm{Cu}$ rrently, CHEMCAD® constitute one of the most used process simulators because of the great number of chemical and petrochemical processes that can be simulated.

Method: The simulation of the production process of styrene via catalytic dehydrogenation of ethyl-benzene is carried out by using the process simulator CHEMCAD ${ }^{\circledR}$ version 5.2.0, in order to determine the composition and mass flow-rate of each process involved in the production, as well as the main operating parameters of the equipment used. Two sensitivity studies were carried out: firstly, the influence of the temperature and pressure values applied at the LLV Separator on the amounts of ethyl-benzene and styrene to be obtained by the intermediate and top
\end{abstract}

currents of this equipment; secondly, the influence of the operating pressure of the Distillation Column No. 1 (benzene-toluene column) on the quantity of ethyl-benzene and styrene obtained at the bottom stream. The simulating software MATLAB ${ }^{\circledR}$ version 7.8.0 was used to process the results obtained.

Results: Around $9234.436 \mathrm{~kg} / \mathrm{h}$ of styrene is obtained in the last distillation column with $99.6 \%$ purity. Additionally, it was found that the water is the main impurity found on this stream, which represents $0.35 \%$ of the weight.

Conclusions: The LLV Separator must operate at a low temperature $\left(5-10^{\circ} \mathrm{C}\right)$ and at a relatively high pressure (10 bar), whereas the Distillation Column No. 1 must work at a pressure near atmospheric (1.0 bar), or preferably under vacuum conditions in order to obtain the highest yields of styrene and ethyl-benzene.

Keywords: $\mathrm{CHEMCAD} \AA$, sensitivity analysis, simulation, styrene, yield.

1 Ingeniero Químico, especialista en simulación de procesos. Docente de la Facultad de Ciencias Aplicadas a la Industria Universidad de Camagüey. Camagüey, Cuba. Contacto: amauryps@nauta.cu

2 Ingeniero Químico, especialista principal de producción. Empresa Industrial Ceballos. Ciego de Ávila, Cuba. Contacto: eddy.perez@reduc.edu.cu

3 Ingeniera Química, especialista en recobrado de productos biotecnológicos y farmacéuticos, magíster en Análisis de Procesos Químicos. Centro de Ingeniería Genética y Biotecnología. Camagüey, Cuba. Contacto: rutdali.segura@cigb.edu.cu 


\section{Resumen}

Contexto: la simulación de procesos se ha venido utilizando extensivamente en los últimos años con el propósito de diseñar, evaluar u optimizar procesos, sistemas u operaciones específicos de la industria química y sus ramas afines. Uno de los simuladores de procesos más empleados en la actualidad es el $\mathrm{CHEMCAD}^{\circledR}$, mediante el cual se pueden simular un gran número de procesos químicos y petroquímicos. Método: se lleva a cabo la simulación del proceso de producción del estireno a partir de la deshidrogenación catalítica del etilbenceno, utilizando el simulador de procesos CHEMCAD ${ }^{\circledR}$ versión 5.2.0., con el fin de conocer la composición y el flujo másico de cada una de las corrientes de proceso, así como también los principales parámetros de operación de los equipos utilizados. Se efectuaron dos estudios de sensibilidad: 1) influencia de los valores de temperatura y presión aplicados en el Separador LLV sobre las cantidades de etilbenceno y estireno a obtener por la corriente intermedia y del tope de este equipo; y 2) influencia de la presión de operación de la Columna de Destilación No. 1 sobre la cantidad de estireno y etilbenceno que sale por el fondo de ésta. Se empleó además el simulador MATLAB ${ }^{\circledR}$, versión 7.8.0, para procesar los resultados obtenidos

Resultados: en la última columna de destilación se obtienen $9234.436 \mathrm{~kg} / \mathrm{h}$ de estireno con un $99.6 \%$ de pureza, siendo la principal impureza encontrada en esta corriente el agua, con $0.35 \%$ en masa.

Conclusiones: el Separador LLV deberá operarse a una temperatura baja $\left(5-10{ }^{\circ} \mathrm{C}\right)$ y a una presión relativamente alta (10 bar), mientras que la Columna de Destilación No. 1 deberá operar a una presión cercana a la atmosférica (1.0 bar) o, preferiblemente, bajo condiciones de vacío, para obtener los mejores rendimientos de estireno y etilbenceno.

Palabras clave: análisis de sensibilidad, CHEM$\mathrm{CAD} \otimes$, estireno, rendimiento, simulación.

\section{INTRODUCTION}

Styrene $\left(\mathrm{C}_{6} \mathrm{H}_{5} \mathrm{CH}=\mathrm{CH}_{2}\right.$; phenyl ethylene, vinyl benzene) is the common name given to the simplest and most important member of the unsaturated aromatic monomers family. It is a very important chemical and is mostly used to obtain daily-use plastic materials and items such as toys, jars, bottles, serving dishes, cups, corks, etc., as well as a foam precursor for insulation and cushioning operations.

Styrene is obtained at commercial scale through several production processes, and the most important are the following (Speight, 2002):

- Catalytic dehydrogenation of ethyl-benzene at high temperature $\left(630{ }^{\circ} \mathrm{C}\right)$ using various metal oxides as catalysts, such as zinc, chromium or magnesium oxides coated on activated carbon, alumina or bauxite.

- Ethyl-benzene oxidation to obtain the hydroperoxide, which then reacts with propylene to give phenyl-methyl-carbinol (or methyl benzyl alcohol) and propylene oxide. The alcohol obtained is then dehydrated to styrene at relatively low temperatures ( 180 to $400{ }^{\circ} \mathrm{C}$ ) by using an acidic silica gel $\left(\mathrm{SiO}_{2}\right)$ or titanium dioxide $\left(\mathrm{TiO}_{2}\right)$ catalyst.

Furthermore, simulation is becoming a requirement for all major process designs. By means of simulation, process engineers can identify potential problems ahead of time and take corrective actions (Towler \& Sinnott, 2008). Common uses for process simulation are process mapping, design, and assessment, as well as cost analysis (Dimian \& Bildea, 2008).

Process simulation and modeling is the application of a range of software tools to analyze individual unit operations (or process stages) and their relationships within the overall process (Boyadjiev, 2010). Process simulation is defined as the utilization of computer software resources to develop 
mathematical models for the construction of an accurate, representative model of a process (a chemical process, in this case), in order to understand its actual behavior during regular plant operations (Diwekar, 2005). These tools can be used at all stages of process development, from conceptual design, through process operation and further optimization. A particular example of the aforementioned constitutes the multi-physics modeling and computational simulation of mass and momentum transfer phenomena in a process of osmotic evaporation by applying Comsol ${ }^{\circledR}$ and Matlab ${ }^{\circledR}$ software (Forero, Pulido \& Cabrera, 2016).

Among the most important process simulators used today in chemical process industries can be mentioned Aspen HYSYS $^{\circledR}$, SuperPro Designer ${ }^{\circledR}$, CADSIM Plus $^{\circledR}$, Gensim ${ }^{\circledR}$, and CHEMCAD ${ }^{\circledR}$.

$\mathrm{CHEMCAD}^{\circledR}$ simulator is primarily designed for the simulation of hydrocarbon treatment and polymer synthesis processes (CHEMSTATIONS, 2002). In that case, refining and chemical processing operations are broadly covered by the unit operations contained in the general program, which also involves using several useful tools such as process sensitivity analysis, equipment design and optimization procedures, project costing, and others (Auli, Sakinah, Bakri, Kamarudin, \& Norazian, 2013).

CHEMCAD $\AA$ simulator has been used in recent years to model and simulate a wide range of processes, such as: the simulation of an olive pits fed rotary kiln pyrolysis plant installed in Southern Italy (Benanti, Freda, Lorefice, Braccio, \& Sharma, 2011); the conceptual design of an acetaldehyde manufacturing plant (Eliasson, 2010); the simulation of the biodiesel production process by transesterification of vegetable oils (Chilev \& Simeonov, 2014), the simulation of a gasification plant equipped with a fluidized bed gasifier (Moneti, Delfanti, Marucci, \& Bedini, 2015); the use of stochastic optimization algorithms for the systematic process retrofit of complex chemical processes (Otte, Lorenz, \& Repke, 2016); the simulation of the formaldehyde production process via Formox technology, and comparison between the obtained and the acquired results using SuperPro Designer process simulator (Johansen, Johnsen, \& Christiansen, 2013); and the conceptual design of a small-scale plant to obtain several components from turpentine oil (Sarwar, 2012).

In this study, the conceptual design and simulation of the styrene production process via catalytic dehydrogenation of ethyl-benzene is carried

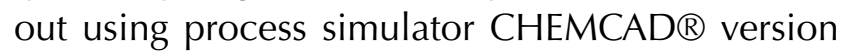
5.2.0 (CHEMSTATIONS, 2002). This research intends to know the mass composition of the different streams involved in the production process, so it is possible to determine the main design parameters of process equipment; to calculate the flow rate of the different auxiliary consumed services (steam, cooling water, etc.); and to graphically evaluate the heat transfer processes carried out at the heat exchangers. To develop this research, there were two sensitivity studies accomplished in order to know which values must be applied to the key operating variables of two processes equipment (LLV Separator and Distillation Column No. 1). This evaluation of variables had as objective to maximize the amount of final product (styrene). The results obtained in this simulation study will help to characterize the production process from the technical point of view; and can be used to take the necessary measures to increase process profitability, yield and productivity; as well as to establish the required fundamentals for future optimization studies.

\section{METHODOLOGY}

\section{Production process description}

The styrene production process using catalytic dehydrogenation of ethyl-benzene was selected for simulation since it constitutes the most employed production process applied at commercial scale to obtain styrene (Speight, 2002). It is composed by four stages: 
1) Ethyl-benzene pre-heating, mixing and vaporization,

2) Dehydrogenation,

3) Cooling, and

4) Separation/Purification.

Figure 1 shows the flow diagram of the production process.

\section{Ethyl-benzene pre-heating, mixing and vaporization}

The production process starts when $10000 \mathrm{~kg} / \mathrm{h}$ of liquid ethyl-benzene stream is pre-heated from ambient temperature $\left(25^{\circ} \mathrm{C}\right)$ to a temperature of about $136{ }^{\circ} \mathrm{C}$ using a shell and tube heat exchanger. The pre-heated stream obtained is then mixed with a recycle stream containing mostly ethyl-benzene and water, and some traces of styrene and toluene, coming from the top of the Distillation Column No. 2 (Styrene Column) in a cylindrical, pressurized vessel (Streams Mixer), operating under isobaric conditions. The exit stream leaving the Stream Mixer is completely vaporized in another shell and tube heat exchanger, until it reaches a temperature of about $250^{\circ} \mathrm{C}$. The vapors obtained are then sent to another pressurized vessel operating also under isobaric conditions (Steam Mixer), at which superheated steam is injected in order to increase the temperature of the vapor mixture to that of the reaction condition $\left(600{ }^{\circ} \mathrm{C}\right)$. The amount of superheated steam to consume in the Steam Mixer should be enough to obtain a gaseous stream with a final water/ethyl-benzene molar ratio of approximately 14:1, prior to being fed to the Conversion Reactor (WVU, 2010).

\section{Catalytic dehydrogenation reaction}

The ethyl-benzene catalytic dehydrogenation takes place in a vertical cylindrical shell and tube reactor (Catalytic Reactor), which operates isothermaIly. The reacting gaseous mixture flows inside the tubes over the catalyst bed, while superheated steam is injected in the reactor's shell to maintain the reaction temperature in the requested range $\left(580-610^{\circ} \mathrm{C}\right)$. The reaction temperature must not be increased to a value higher than $610{ }^{\circ} \mathrm{C}$ since thermal decomposition of both ethyl-benzene and styrene would occur. At the reactor's exit a hot gaseous mixture is obtained, which has a styrene mass composition of about $93 \%$ (on dry basis).

\section{Cooling}

The hot gaseous mixture coming from the Catalytic Reactor, which presents a temperature near $600{ }^{\circ} \mathrm{C}$ and a pressure of $3.5 \mathrm{bar}$, is pressurized to $6.0 \mathrm{bar}$ using pressure regulating valves. Then, the mixture is cooled to $50{ }^{\circ} \mathrm{C}$ via two shell and tube heat exchangers (Coolers), which use cooling water as the heat exchanging agent. A two-phase (vapor-liquid) stream with approximately $50^{\circ} \mathrm{C}$ temperature is obtained at the exit of the second cooler, which is then sent to the Separation/Purification area.

\section{Separation/Purification}

The styrene present at the exit stream of the Conversion Reactor must be separated and purified from the rest of the other chemicals contained on it (water, toluene, etc.). To accomplish this, the two-phase stream obtained at the exit of the coolers is sent to a three-phase separator (Liquid-Liquid-Vapor Separator or LLV Separator), which operates at 5 bar and $50{ }^{\circ} \mathrm{C}$. A gaseous mixture primarily composed by hydrogen, methane and ethylene (as well as minor amounts of water and styrene) is obtained at the top of the LLV Separator (light gaseous stream), while a liquid stream containing water and certain traces of styrene, benzene and ethylene is obtained at the bottom of this equipment (wastewater stream). The middle stream (useful stream) contains mainly styrene, as well as minor amounts of the other chemicals, and is sent to the Distillation Column No. 1 (Benzene-Toluene Column), in order to recover both the benzene and toluene contained on it, and also for styrene concentration.

Both the benzene and toluene are obtained at the top of the Distillation Column No. 1 while a styrene-rich stream is obtained at the column's bottom, which is sent to the Distillation Column No. 2 (Styrene Column) to carry out the final purification 
step. At the Styrene Column, the styrene is obtained at the bottom stream with a purity of about $99.5 \%$ while the stream obtained at the top of this column (composed mostly by ethylbenzene, benzene and toluene) is recycled back to the process (Recycle Stream) and mixed with the pure ethylbenzene stream which had previously been preheated at the first shell and tube heat exchanger.

Since pure styrene could polymerize spontaneously in presence of high temperature and high pressure (typically over 6 bar and $125^{\circ} \mathrm{C}$ ), it is necessary to carry out the distillation process at the lowest possible pressure. This should also be done to avoid the polymerization of the vinyl aromatic chemicals created during the reaction step, considering that the Benzene-Toluene Column operates at a pressure of 1.5 bars while the secondary distillation operation accomplished at the Styrene Column is carried out at 1.0 bar (atmospheric distillation).

\section{Catalyst}

Currently, several metallic oxides are used as catalysts to obtain styrene from ethyl-benzene. In this process, iron oxide (III) supported on alumina would be used as the main catalyst (Snyder \& Subramaniam, 1994); it presents a density of 1282 $\mathrm{kg} / \mathrm{m}^{3}$ and a void fraction of 0.4 .

\section{Thermodynamic model selection}

PSRK (Peng-Soave-Redlich-Kwong) vapor-phase associated thermodynamic model was selected to carry out simulation calculations in $\mathrm{CHEMCAD}{ }^{\circledR}$ simulator (CHEMSTATIONS, 2002). This model fits better the temperature and pressure ranges handled throughout the production process, and it's also capable of predicting satisfactorily the most important thermodynamic variables of all the chemicals used according to the different existing phases. Using this model and the SRK model (Soave-Redlich-Kwong) allows determining the values of the equilibrium constant $\mathrm{K}$ and other important thermodynamic parameters. Additionally, it is taken into account some useful recommendations provided by the simulator itself (CHEMSTATIONS, 2002).

\section{Sensitivity studies}

Once the simulation approach was accomplished, two sensitivity studies were carried out using the tool "Sensitivity Study" contained within the process simulator. The first consists of evaluating how both the operating temperature and pressure applied to the LLV Separator affect the amount of styrene and ethyl-benzene obtained at the middle stream. The temperature varied from 30 to $80{ }^{\circ} \mathrm{C}$, while the pressure was modified from 5 to 10 bar.

The second sensitivity study determines if the operating pressure applied at the Benzene-Toluene Column influences the amount of styrene and ethyl-benzene obtained in the column's bottom stream. In addition, the study establishes if the operating pressure also affects the number of stages (plates) required to accomplish the expected separation. In this case, the operating pressure varied from 1 to 6 bars.

\section{Description of the chemical reactions involved}

Equations (1) (2) and (3) represent the main reactions that take place inside the Catalytic Reactor, which are the catalytic dehydrogenation of ethyl-benzene to obtain styrene and hydrogen (equation 1); benzene and toluene formation from ethyl-benzene (equation 2); and the reaction of ethyl-benzene with hydrogen to obtain toluene and methane (equation 3). The application of high temperatures during reaction step permits the catalytic dehydrogenation of ethyl-benzene to be the predominant reaction, with a selectivity of about 95\% (Snyder \& Subramaniam, 1994) while the rest of the reactions involved totalize about $4 \%$. The most important reactions occurring inside the reactor, as well as its reaction kinetics, are shown below (Snyder \& Subramaniam, 1994) (WVU, 2010). 


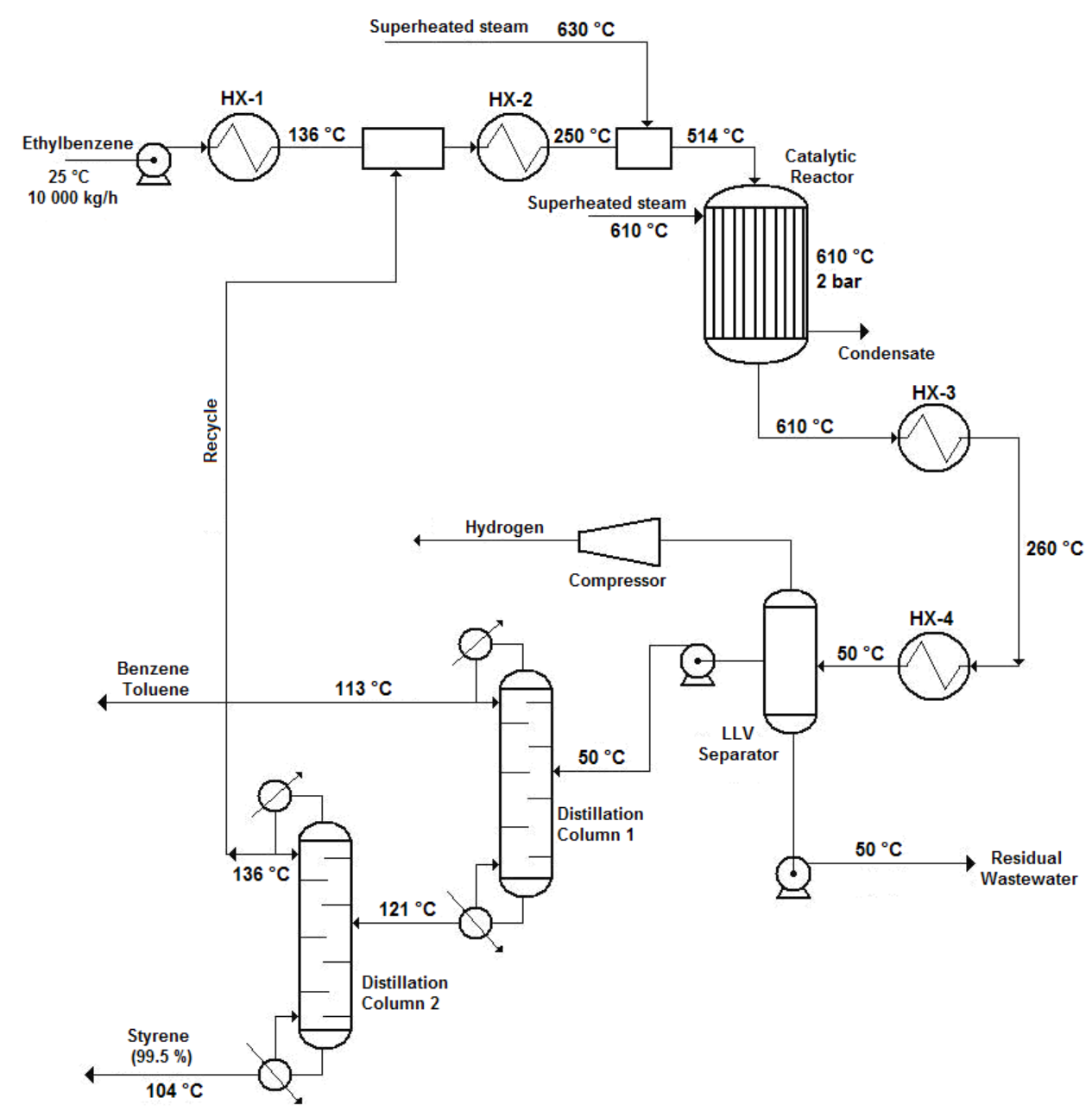

Figure 1. Flow diagram of the styrene production process via catalytic dehydrogenation of ethyl-benzene Source: own work

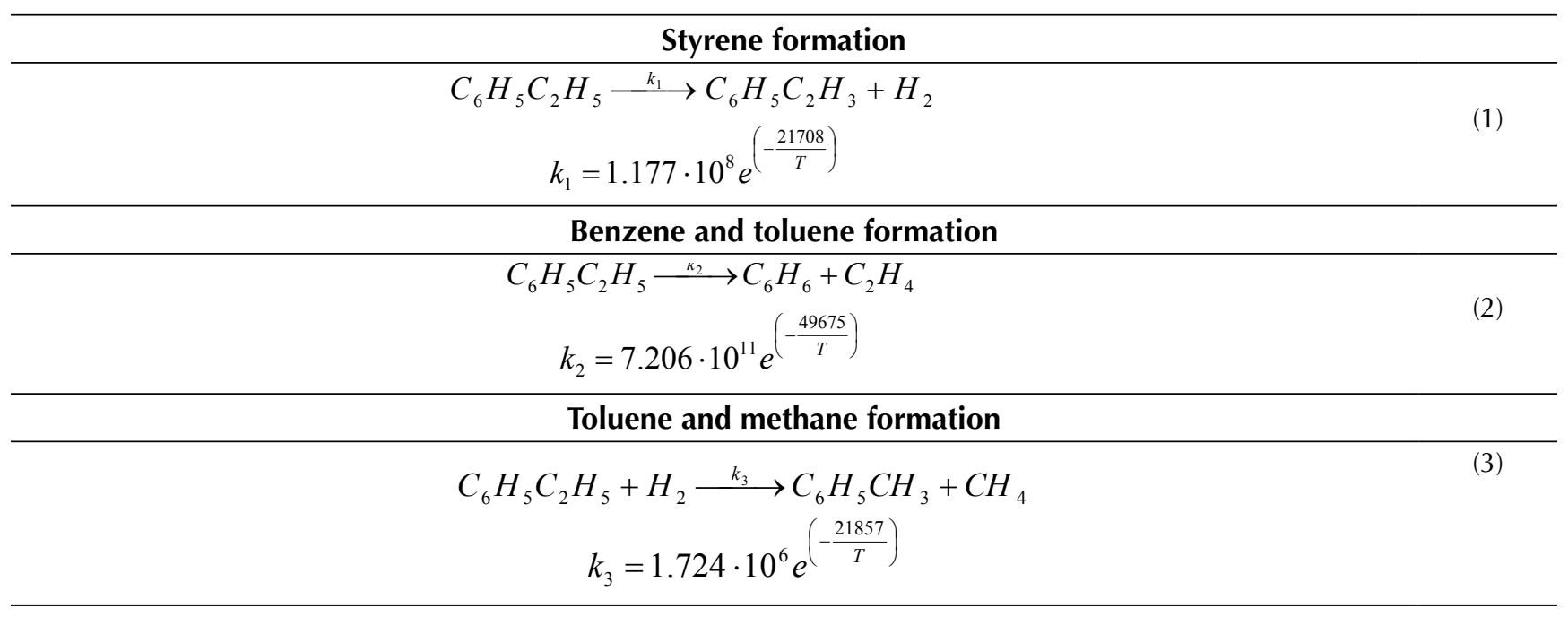

Where $T$ is in $K$ 


\section{Process simulation}

Figure 2 shows the flow diagram obtained during process simulation in $\mathrm{CHEMCAD} \otimes$ simulator.

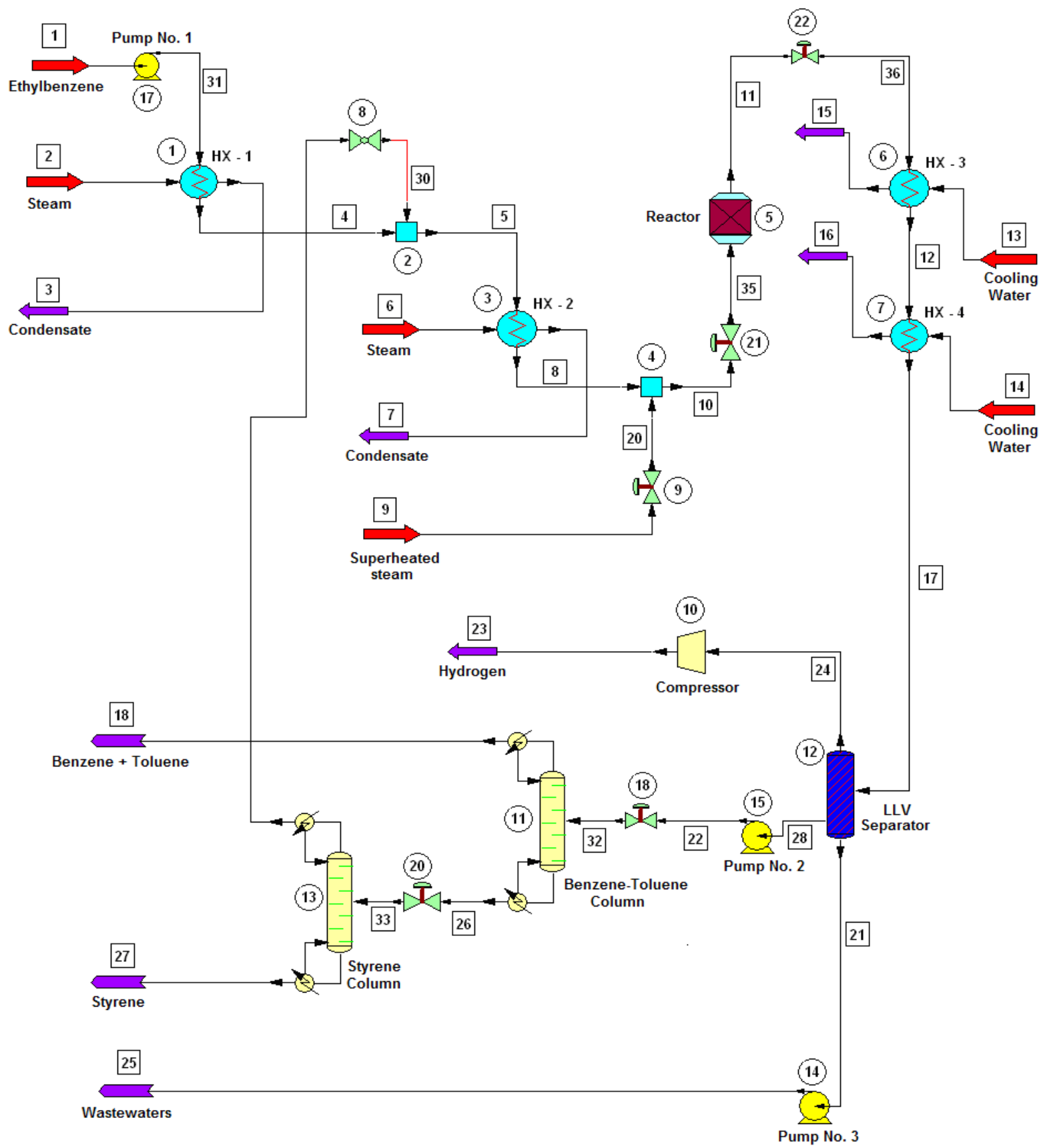

Figure 2. Flow diagram of the styrene production process obtained by $\mathrm{CHEMCAD} ®$ simulator Source: $\mathrm{CHEMCAD}{ }^{\circ}$ 


\section{RESULTS}

The results obtained regarding composition of the intermediate and exit streams, equipment design variables, heat curves, and the two sensitivity studies carried out, are shown in the following sections. Figure 3 presents the results obtained for the shell and tube heat exchangers regarding $\%$ of heat exchanged, LMDT, heat transfer area and auxiliary service flow-rate.

\section{Equipment}

\section{Shell and tube heat exchangers}

According to the results shown in figure 3, the heat exchanger number 4 was the one that transferred the highest amount of heat $(68.34 \%$ of the total). This is because this equipment presents the
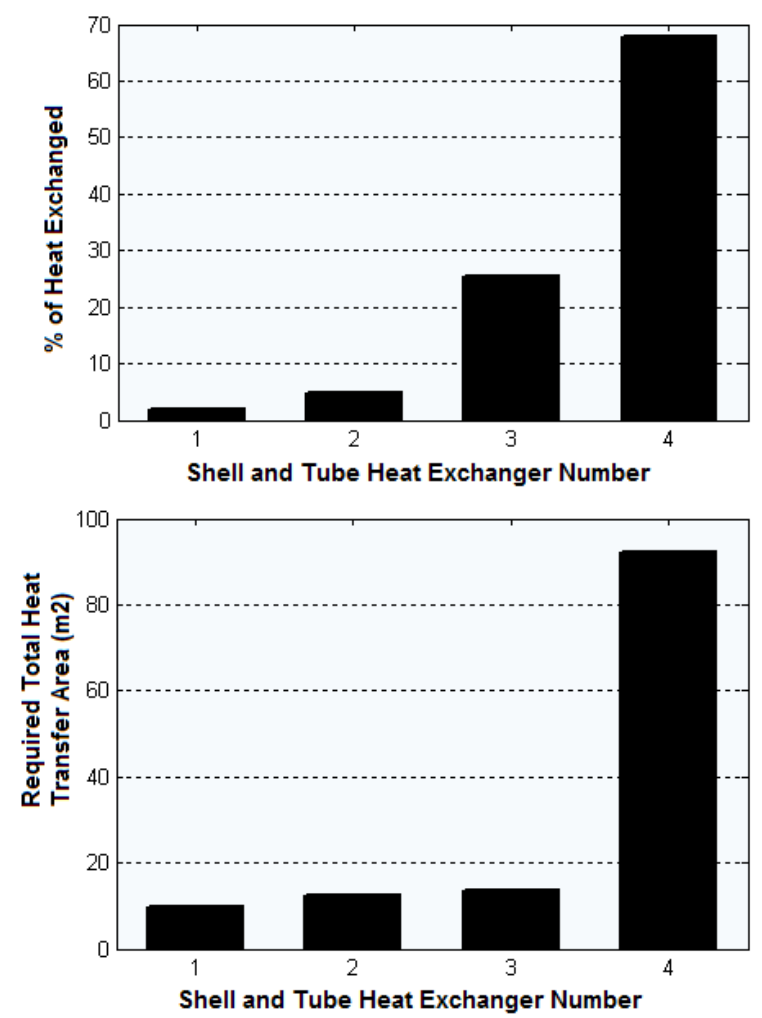

condensation of the components in the reacting gaseous mixture from $260{ }^{\circ} \mathrm{C}$ to approximately 50 ${ }^{\circ} \mathrm{C}$. The heat exchanger number 3 had the highest value of the Logarithmic Mean Temperature Difference (LMTD), with $372.841{ }^{\circ} \mathrm{C}$, since this heat exchanger presents the highest temperature difference between the hot fluid inlet temperature $(=$ $611.2{ }^{\circ} \mathrm{C}$ ) and the cold fluid exit temperature ( $=45$ $\left.{ }^{\circ} \mathrm{C}\right)$, which is $566.2{ }^{\circ} \mathrm{C}$ (Cao, 2010).

On the other hand, the heat exchanger number 4 had the highest value of calculated heat transfer area $\left(92.23 \mathrm{~m}^{2}\right)$. This is because this heat exchanger presents the highest heat transfer duty combined with a low value of the LMTD parameter (Cao,

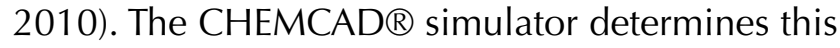
parameter according to equation (4).

$$
A=\frac{Q}{U \cdot L M T D}
$$
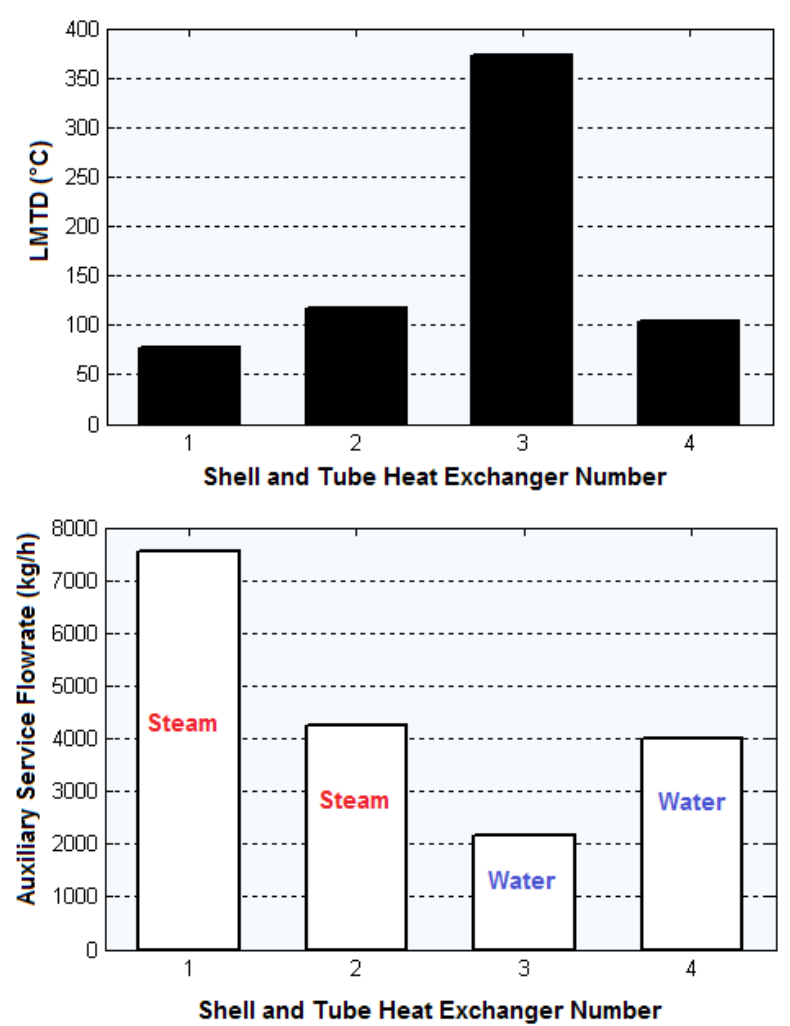

Figure 3. Results obtained for the shell and tube heat exchangers

Source: own work 
Where $\mathrm{Q}$ is the exchanged heat $[\mathrm{kcal} / \mathrm{h}]$ and $U$ is the overall heat transfer coefficient $[\mathrm{kcal} / \mathrm{h}$. $\left.\mathrm{m}^{2} .{ }^{\circ} \mathrm{C}\right]$. According to this expression, the greater the value of the numerator $(Q)$, the greater the result of the heat transfer area (A) (Cao, 2010).

The heat exchanger number 1 requested the highest amount of steam (7 $559.9 \mathrm{~kg} / \mathrm{h}$ ). This is because this equipment accomplishes the pre-heating process of the liquid ethyl-benzene stream (10 $000 \mathrm{~kg} / \mathrm{h})$ from ambient temperature $\left(25^{\circ} \mathrm{C}\right)$ to a temperature near the evaporation point $\left(136{ }^{\circ} \mathrm{C}\right)$, which involves the demand of great amounts of this auxiliary service to meet this significant temperature increment $\left(111^{\circ} \mathrm{C}\right)$.
Finally, the heat exchanger number 4 needed the highest flow of cooling water $(4008.8 \mathrm{~kg} / \mathrm{h})$ because that is the place where phase change (condensation) of the hot reacting mixture occurs from a temperature of $260{ }^{\circ} \mathrm{C}$ to approximately $50{ }^{\circ} \mathrm{C}$ (temperature difference of $210^{\circ} \mathrm{C}$ ); this process releases great amounts of heat that must be compensated with an elevated flow of the cooling agent.

Table 1 displays the total heat values of the reaction determined by the $\mathrm{CHEMCAD} \mathbb{R}$ simulator for the conversion reactor, while tables 2, 3 and 4 show the results obtained for the two distillation columns, the centrifugal pumps and the adiabatic compressor, respectively.

Table 1. Total reaction heat for the catalytic reactor determined by CHEMCAD® simulator

\begin{tabular}{lc}
\hline \multicolumn{1}{c}{ Parameter } & Value \\
\hline Total heat of reaction $[\mathrm{kJ} / \mathrm{h}]$ & 10639000 \\
\hline
\end{tabular}

Source: own work

Table 2. Results obtained for distillation columns by CHEMCAD® simulator

\begin{tabular}{lcc}
\hline \multicolumn{1}{c}{ Parameter } & \multicolumn{2}{c}{ Value } \\
\cline { 2 - 3 } & Column 1 & Column 2 \\
\hline Condenser heat duty $[\mathrm{kJ} / \mathrm{h}]$ & -5063360 & -426319 \\
\hline Reboiler heat duty $[\mathrm{kJ} / \mathrm{h}]$ & 6445640 & 243804 \\
\hline Minimum number of stages & 34 & 48 \\
\hline Feed plate (stage) & 25 & 59 \\
\hline Total number of plates (stages) & 57 & 95 \\
\hline Top stream (distillate) temperature $\left[{ }^{\circ} \mathrm{C}\right]$ & 112.786 & 143.600 \\
\hline Bottom stream (residue) temperature $\left[{ }^{\circ} \mathrm{C}\right]$ & 121.190 & 111.000 \\
\hline
\end{tabular}

Source: own work

Table 3. Results obtained for the centrifugal pumps by CHEMCAD® simulator

\begin{tabular}{|c|c|c|c|}
\hline Pump & $\begin{array}{c}\text { Power } \\
\text { [kW] }\end{array}$ & $\begin{array}{c}\text { Head } \\
{[\mathrm{m}]}\end{array}$ & $\begin{array}{c}\text { Flow rate } \\
{\left[\mathrm{m}^{3} / \mathrm{h}\right]}\end{array}$ \\
\hline 1 & 3.408 & 106.3 & 11.6 \\
\hline 2 & 1.020 & 32.6 & 11.0 \\
\hline 3 & 8.250 & 152.8 & 25.2 \\
\hline 4 & 4.625 & 68.9 & 18.6 \\
\hline 5 & 6.524 & 89.5 & 21.4 \\
\hline
\end{tabular}

Source: own work 
Table 4. Results obtained for the adiabatic reciprocating compressor by CHEMCAD® simulator

\begin{tabular}{lcc}
\hline & Parameter & Value \\
\hline $\mathrm{Cp} / \mathrm{Cv}$ & 1.376 \\
\hline Ideal $\mathrm{Cp} / \mathrm{Cv}$ & 1.373 \\
\hline Theoretical power $[\mathrm{kW}]$ & 86.994 \\
\hline
\end{tabular}

Source: own work

The second distillation column needs the highest number of stages since it is the place where occurs the final separation of the styrene from the rest of the chemical components contained in the feed stream (including the ethyl-benzene, which presents a boiling point value near to the styrene's). This final separation allows obtaining styrene with a final purity of about $99.5 \%$, which is the purity requested for the styrene, and the similarity of the styrene's boiling point to the ethyl-benzene implicates that a high number of stages will be needed at this column to obtain this separation request.

\section{Heat curves}

Several heat curves were obtained for each shell and tube heat exchanger used in the process employing the tool "Plot Heat Curve" contained within the CHEMCAD ${ }^{\circledR}$ simulator. These curves show the existing relationship between temperatures of both fluids versus heat exchanger length (\%), thus obtaining a spatial temperature profile describing the thermal behavior of the heat exchange process with regards to the equipment length. In this case, since every heat exchanger works at true countercurrent flow, in each one of these graphs the inlet point of one fluid will be the exit point of the other fluid.

Figures $4 \mathrm{a}$ to $4 \mathrm{~d}$ display the heat curves obtained for each heat exchanger. It can be observed that the heat curve obtained for the ethyl-benzene stream at the heat exchanger No. 1 presents an ascending lineal behavior without deviation points while the cooling curve obtained for the gaseous stream in the heat exchanger No. 3 (figure 4c) presents this constant lineal pattern, but in descending mode. This means that none of these cases present a phase change for the process stream handled in the heat exchanger, which is correct since at the heat exchanger No. 1 the ethyl-benzene stream is pre-heated without undergoing evaporation, and the gaseous stream obtained at the reactor's exit is cooled in the heat exchanger No. 3 without condensation.

Both heat curves obtained for the heat exchangers number 2 (figure $4 \mathrm{~b}$ ) and 4 (figure $4 \mathrm{~d}$ ) present nonlinear thermal patterns with turning points, which indicate that there are phase change processes occurring on them (i.e. vaporization in the heat exchanger number 2 and condensation in the number 4). This can be confirmed by assessing the thermal behavior of each process stream on the heat curves obtained. According to the heat curve obtained for the heat exchanger number 2 (figure 4b), the process stream follows a lineal heating pattern (sensible heat) until reaching a point near $50 \%$ of the heat exchanger length, at which phase change occurs (vaporization). Once vaporized, the gaseous mixture will follow the same lineal heating pattern, but with reduced temperature increments, until achieving the desired final temperature $\left(250^{\circ} \mathrm{C}\right)$.

Finally, considering the heat curve obtained for the heat exchanger No. 4 (figure 4d), the previously cooled gaseous mixture follows a lineal cooling pattern until reaching $90 \%$ of the heat exchanger length; this is the moment when phase change (condensation) occurs. From this point the liquid mixture is cooled, showing a nonlinear behavior in a form of a decreasing curve, until it reaches the desired temperature $\left(50^{\circ} \mathrm{C}\right)$. 


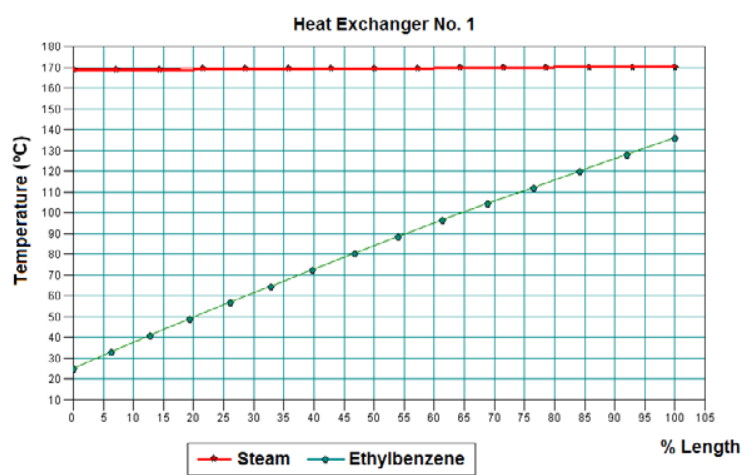

a)

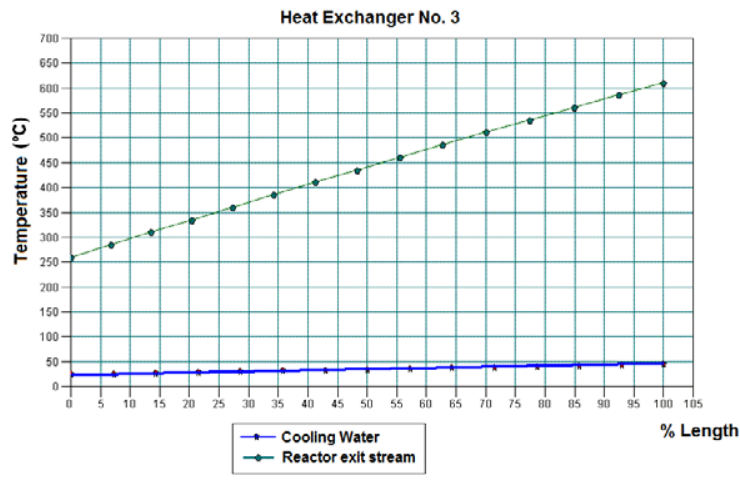

c)

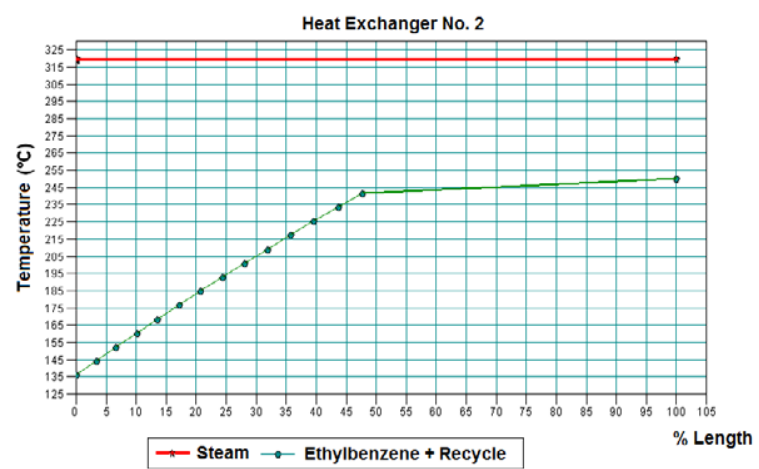

b)

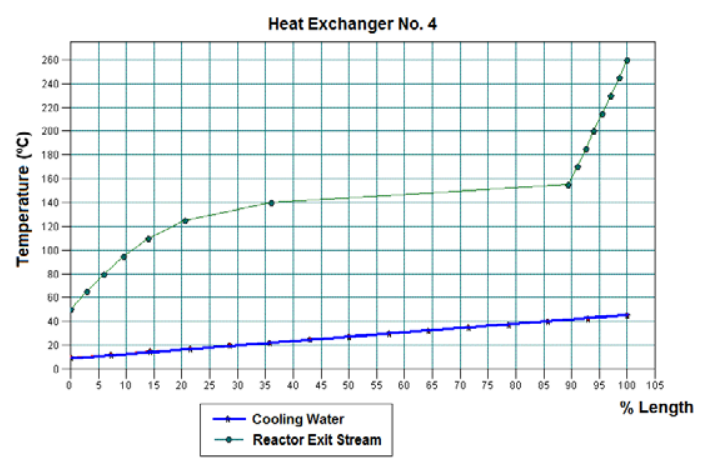

d)

Figure 4. Heat curves obtained of the four shell and tube heat exchangers employed in the process

Source: $\mathrm{CHEMCAD} \otimes$

\section{Inlet and outlet streams}

Tables 5, 6 and 7 show the mass flow rate values of both inlet and outlet streams for each process equipment, obtained with $\mathrm{CHEMCAD} \mathbb{R}$ simulator.

Table 5. Calculated mass flow rates of both inlet and outlet streams for the conversion reactor

\begin{tabular}{lcc}
\hline & Compound & \multicolumn{2}{c}{ Mass Flow rate (kg/h) } & Outlet \\
\cline { 2 - 3 } & Inlet & 25000.000 \\
\hline Water & 25000.000 & 20.000 \\
\hline Ethyl-benzene & 10000.720 & 9320.455 \\
\hline Styrene & 0.092 & 176.024 \\
\hline Hydrogen & - & 183.955 \\
\hline Benzene & 0.000017 & 199.630 \\
\hline Toluene & 0.002 & 66.066 \\
\hline Ethylene & - & 34.758 \\
\hline Methane & 35000.814 & 35000.888 \\
\hline
\end{tabular}

Source: own work 
Table 6. Calculated mass flow rates of both inlet and outlet streams for the LLV Separator

\begin{tabular}{lrrrr}
\hline \multirow{2}{*}{ Compound } & \multicolumn{4}{c}{ Mass Flow rate $\mathbf{( k g / h )}$} \\
\cline { 2 - 5 } & \multirow{2}{*}{ Inlet } & \multicolumn{1}{c}{ Outlet } \\
\cline { 3 - 5 } & & \multicolumn{1}{c}{ Top } & \multicolumn{1}{c}{ Middle } & \multicolumn{1}{c}{ Bottom } \\
\hline Water & 25000.000 & 42.144 & 48.037 & 24909.820 \\
\hline Ethyl-benzene & 20.000 & 0.188 & 19.794 & 0.019 \\
\hline Styrene & 9320.455 & 72.908 & 9235.452 & 12.095 \\
\hline Hydrogen & 176.024 & 175.499 & 0.357 & 0.167 \\
\hline Benzene & 183.955 & 12.562 & 169.601 & 1.791 \\
\hline Toluene & 199.630 & 4.509 & 194.676 & 0.445 \\
\hline Ethylene & 66.066 & 61.701 & 3.164 & 1.201 \\
\hline Methane & 34.758 & 34.339 & 0.379 & 0.040 \\
\hline Total & 35000.888 & 403.850 & 9671.460 & 24925.578 \\
\hline
\end{tabular}

Source: own work

Table 7. Calculated mass flow rates of the inlet and outlet (top and bottom) streams for the distillation columns

\begin{tabular}{lrrrrrr}
\hline \multirow{2}{*}{ Compound } & \multicolumn{7}{c}{ Mass Flow rate (kg/h) } \\
\cline { 2 - 8 } & \multicolumn{2}{c}{ Distillation Column 1 } & \multicolumn{2}{c}{ Distillation Column 2 } \\
\cline { 2 - 8 } & \multicolumn{1}{c}{ Inlet } & Top & Bottom & Inlet & Top & Bottom \\
\hline Water & 48.037 & - & 48.037 & 48.037 & 9.525 & 38.512 \\
\hline Ethyl-benzene & 19.794 & 19.077 & 0.717 & 0.717 & 0.717 & - \\
\hline Styrene & 235.452 & 0.924 & 9234.528 & 9234.528 & 0.092 & 9234.436 \\
\hline Hydrogen & 0.357 & 0.357 & - & - & - & - \\
\hline Benzene & 169.601 & 169.601 & - & - & - & - \\
\hline Toluene & 194.676 & 194.674 & 0.002 & 0.002 & 0.002 & - \\
\hline Ethylene & 3.164 & 3.164 & - & - & - & - \\
\hline Methane & 0.379 & 0.379 & - & - & - & - \\
\hline Total & 9671.460 & 388.176 & 9283.284 & 9283.284 & 10.336 & 9272.948 \\
\hline
\end{tabular}

Source: own work

According to the results showed in tables 7 and 8, near 99\% of the styrene fed to the LLV Separator is recovered on its middle stream, while about $100 \%$ of the benzene and toluene fed to the Distillation Column No. 1 is recovered in the top stream of this column. Finally, styrene is obtained at the Distillation Column No. 2 with a purity of about $99.6 \%$, while near $0.72 \mathrm{~kg} / \mathrm{h}$ of ethyl-benzene are recycled back to the production process.

\section{Results of the sensitivity studies}

\section{Sensitivity study No. 1}

Figure 5 shows the results obtained for sensitivity study No. 1 . In this case, the figure 5 a represents the existing relationship between the ethyl-benzene flow rates at the middle stream of the LLV separator versus the operating temperature. Figure $5 b$ indicates the existing relationship between the 
styrene flow rates at the middle stream of the LLV separator versus the operating temperature. Figure $5 c$ shows the existing relationship between the ethyl-benzene flow rates at the top stream of the LLV separator versus the operating temperature. Figure $5 d$ presents the existing relationship between the styrene flow rates at the top stream of the LLV separator versus the operating temperature. Figure 5e presents the existing relationship between the ethyl-benzene flow rates at the middle stream of the LLV separator versus the operating pressure. Figure $5 f$ displays the existing relationship between the styrene flow rates at the middle stream of the LLV separator versus the operating pressure. Figure $5 \mathrm{~g}$ shows the existing relationship between the ethyl-benzene flow rates at the top stream of the LLV separator versus the operating pressure. FinaIly, figure $5 \mathrm{~h}$ displays the existing relationship between the styrene flow rates at the top stream of the LLV separator versus the operating pressure.

From the results, it can be concluded that both an increment of the working temperature and a reduction of the internal pressure in the LLV Separator will lead to an increment of the obtained amounts of ethyl-benzene and styrene at the top stream of this equipment. That means an evaporation increment of both components, which is undesirable and could be considered as loss.

Therefore, a temperature increment of $20{ }^{\circ} \mathrm{C}$ will lead to approximately $15 \mathrm{~kg} / \mathrm{h}$ of styrene losses, while nearly $0.041 \mathrm{~kg} / \mathrm{h}$ of ethyl-benzene will not be recycled back to the process. With the objective of increasing the amount of obtained chemicals (ethyl-benzene and styrene) in the middle stream of the LLV Separator, this equipment must be operated at $5{ }^{\circ} \mathrm{C}$, and a pressure near 10 bar, that is, under cooling and pressurized conditions.

\section{Sensitivity study No. 2}

The results obtained for the Sensitivity study No. 2 can be observed in figure 6 . Figure 6 a represents the existing relationship between the ethyl-benzene flow rates the bottom stream of Distillation Column No. 1 versus the operating pressure. Figure $6 b$ shows the existing relationship between the styrene flow rates the bottom stream of Distillation Column No. 1 versus the operating pressure. Figure 5c presents the existing relationship between the stages of the Distillation Column No. 1 versus the operating pressure.

Taking into account the results showed in figures $6 a-6 c$, it can be concluded that an increment of the working pressure at the Distillation Column No. 2 would reduce the amounts of both styrene and ethyl-benzene at the bottom stream of this equipment, while the total number of plates (separation stages) would increase in order to achieve the desired separation request. Both results are not acceptable from styrene yield and equipment cost points of view, since it will generate undesirable losses of the main product and increase also the geometrical dimensions (size) of the column, thus increasing its purchasing cost.

In this case, an increment of the column's operating pressure will also increase the internal operating temperature of the column and the number of plates (stages) required to carry out the desired separation duty. The amounts for both styrene and ethyl-benzene to obtain at the top stream of the column will increase as well, due to an increment of the evaporation of both components. Considering the aforementioned, the distillation column must operate at the minimum required operating pressure in order to obtain an economical column in terms of required separation stages, from which the highest amounts of both styrene and ethyl-benzene could be obtained at the bottom stream. 
Simulation of the Styrene Production Process Via Catalytic Dehydrogenation Of Ethylbenzene Using CHEMCAD® Process Simulator Pérez, A., Pérez, E. y Segura, R.
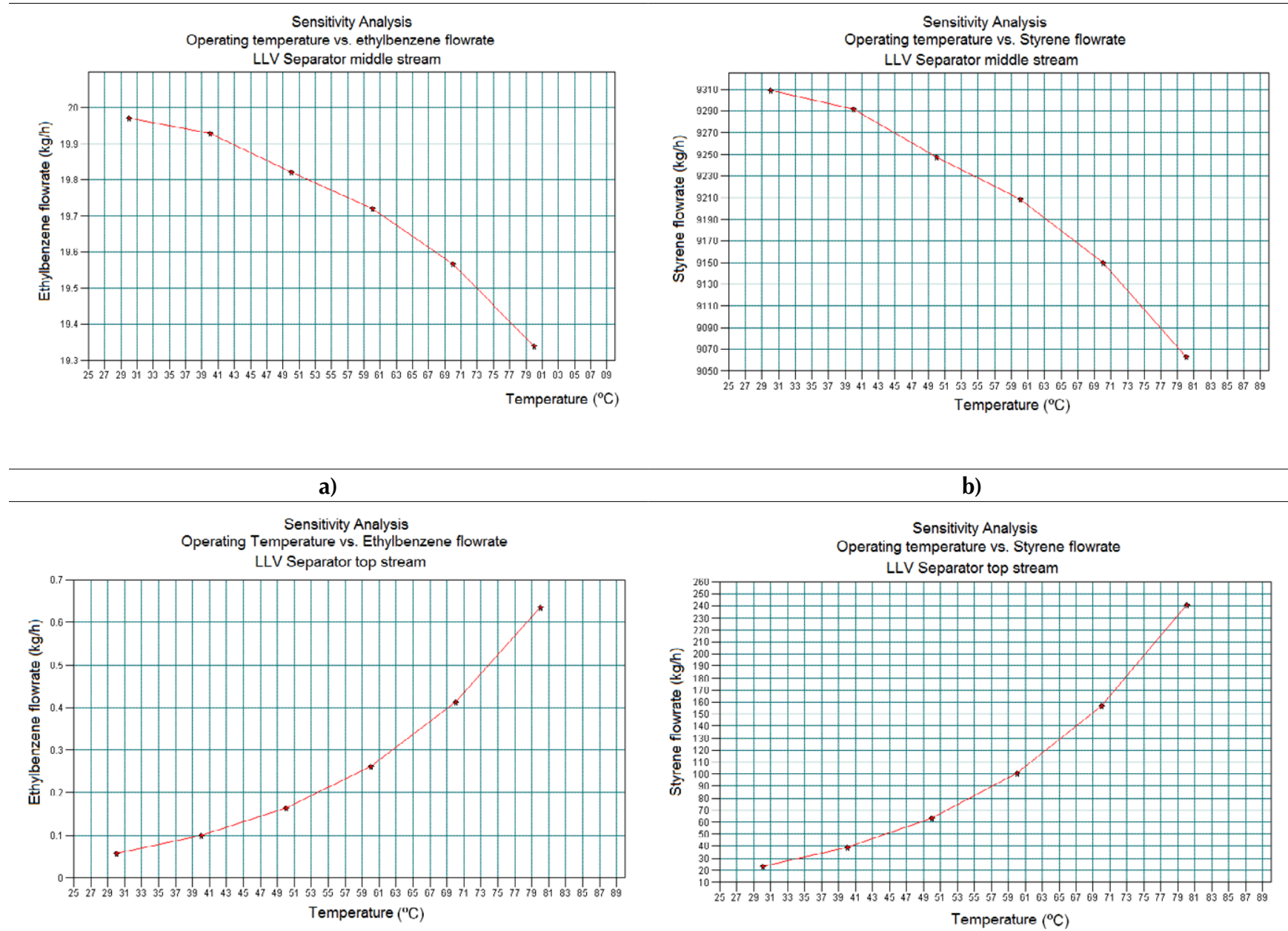

b)

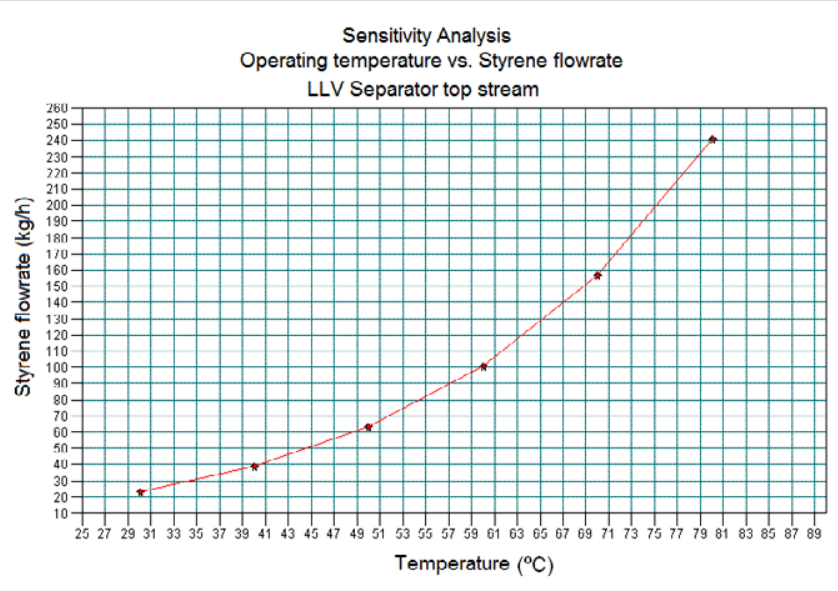

c)

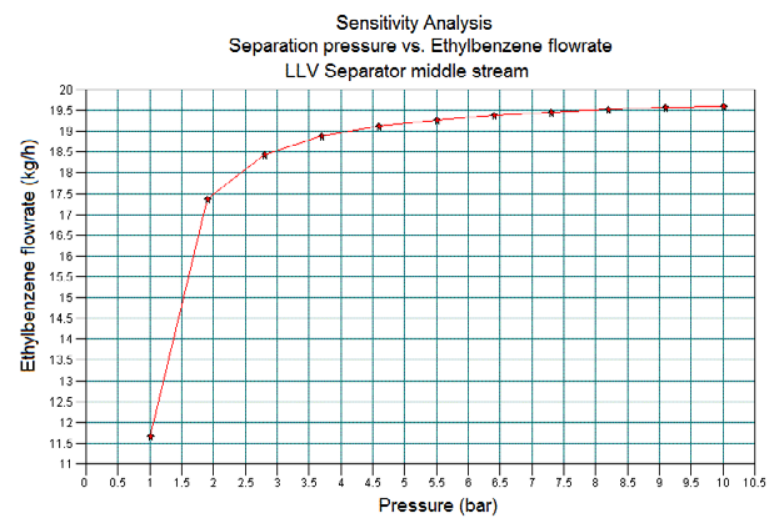

d)

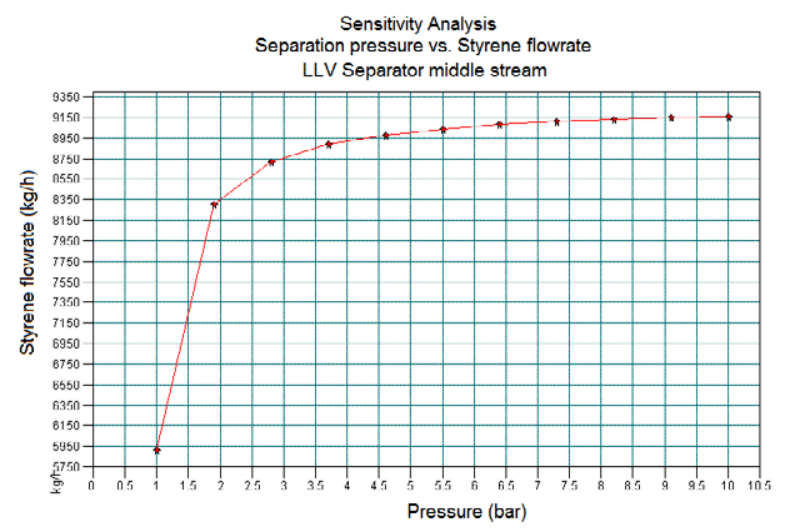




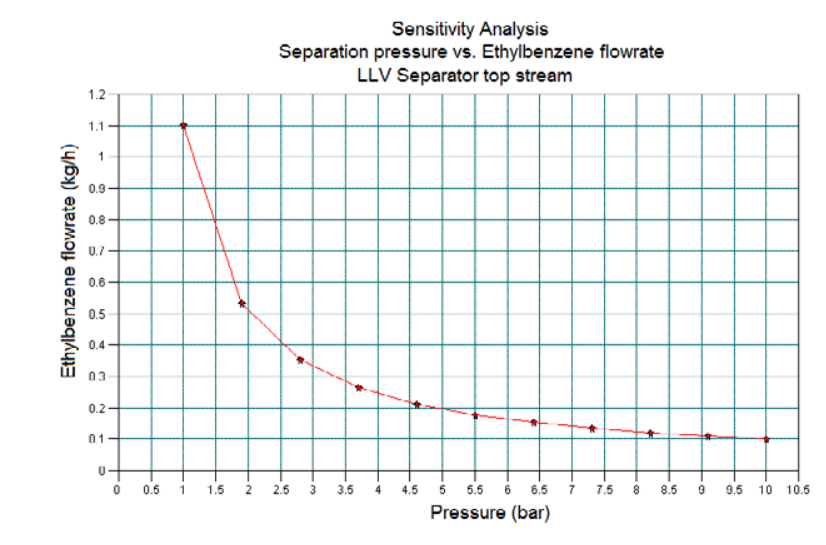

g)

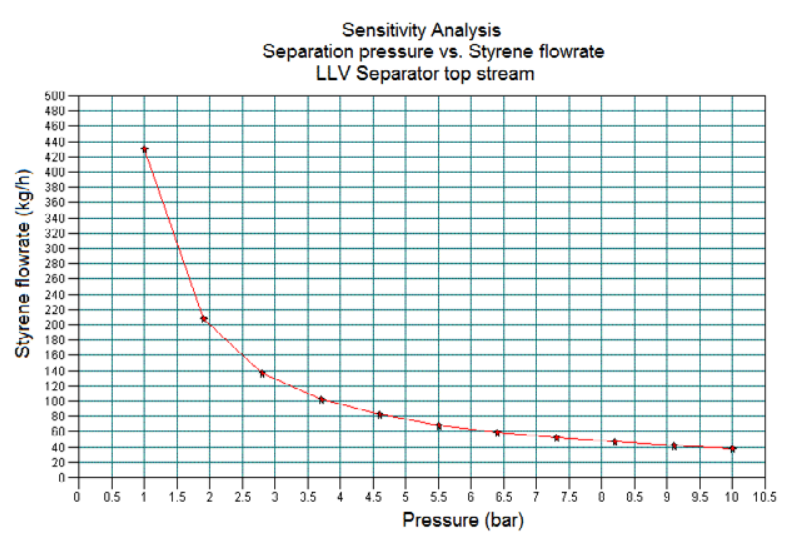

h)

Figure 5. Results obtained in the Sensitivity Study No. 1 by means of CHEMCAD® simulator

\section{Source: $\mathrm{CHEMCAD}{ }^{\circledR}$}

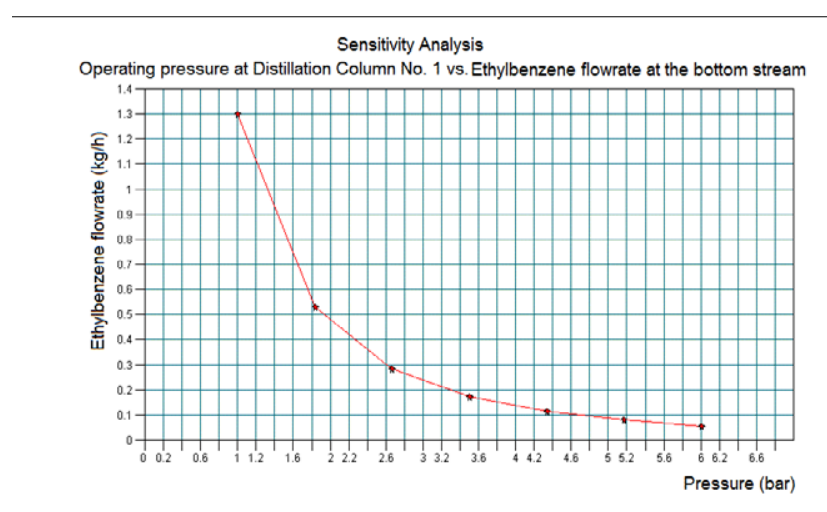

a)

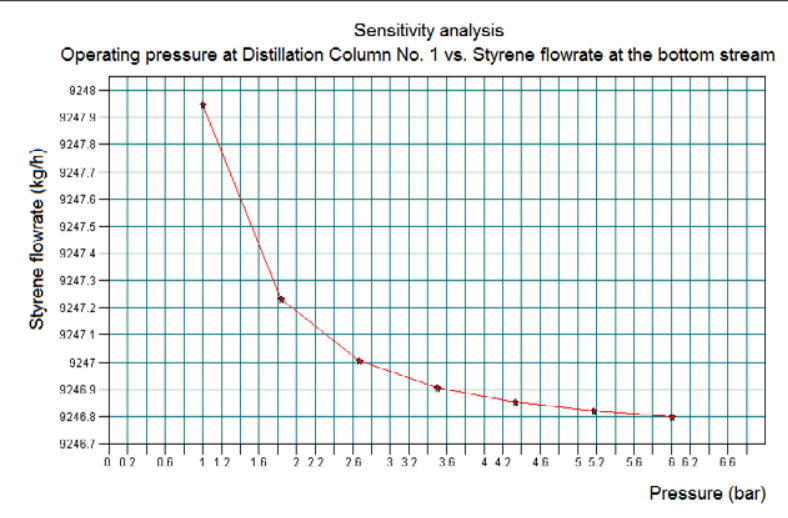

b)

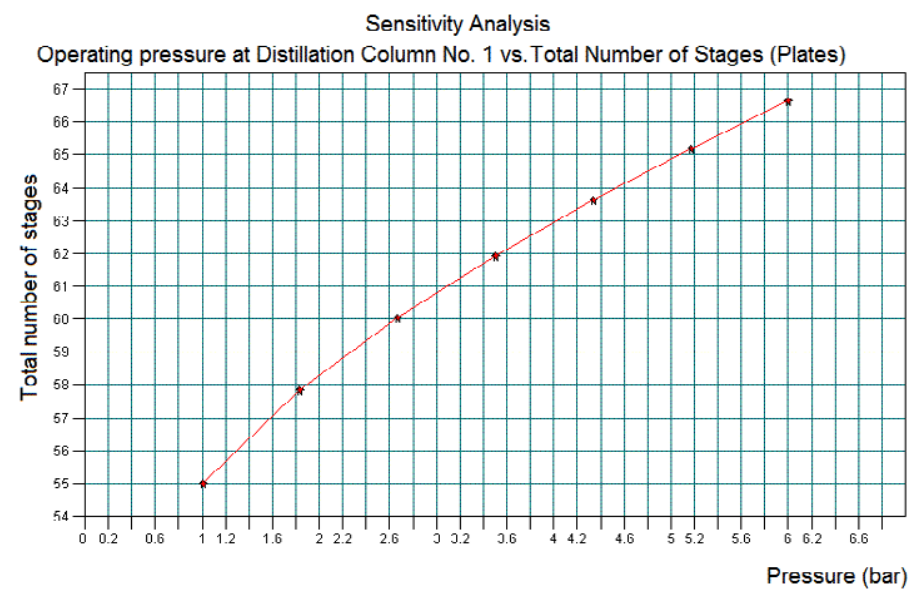

c)

Figure 6. Results obtained in the Sensitivity Study No. 2 by means of CHEMCAD® simulator

Source: $\mathrm{CHEMCAD}{ }^{\circledR}$ 


\section{CONCLUSIONS}

The use of $\mathrm{CHEMCAD} \otimes$ simulator allowed simulating successfully the production process of styrene via catalytic dehydrogenation of ethyl-benzene.

Styrene is obtained at the bottom stream of the Distillation Column No. 2 with a purity of about $99.6 \%$, and the water is the main impurity on it $(\sim 0.35 \%)$.

The heat exchanger that requires the highest amount of steam is the No. 1, with $7559.9 \mathrm{~kg} / \mathrm{h}$.

The heat exchanger that requests the highest amount of cooling water is the No. 4, with $4008.8 \mathrm{~kg} / \mathrm{h}$.

The heat curves obtained for all the heat exchangers permit to analyze and evaluate the temperature profiles followed by each stream related to the equipment length.

Distillation Column No. 1 requires 57 stages (plates) to carry out the desired separation duty, while the Distillation Column No. 2 will need about 97 stages.

The LLV Separator must operate at $5{ }^{\circ} \mathrm{C}$ of temperature, and at a pressure of $10 \mathrm{bar}$, in order to reduce losses of styrene and ethyl-benzene at the top stream of this equipment.

The Distillation Column No. 1 must operate at atmospheric temperature or under vacuum conditions in order to obtain greater amounts of styrene and ethyl-benzene at the top stream of this equipment, and also to reduce column geometry and, thus costs.

\section{REFERENCES}

Auli, N., Sakinah, M., Bakri, A., Kamarudin, H. \& Norazian, M. (2013). Simulation of Xylitol Production: A Review. Australian Journal of Basic and Applied Sciences, 7(5), 366-372.

Benanti, E., Freda, C., Lorefice, V., Braccio, G., \& Sharma, V. (2011). Simulation of Olive Pits Pyrolysis in a Rotary Kiln Plant. Thermal Science, 15(1), 145-158.
Boyadjiev, C. (2010). Theoretical Chemical Engineering: Modeling and Simulation. New York: Springer-Verlag.

Cao, E. (2010). Heat Transfer in Process Engineering. New York: McGraw-Hill.

Chemstations. (2002). ChemCAD Professional' (Version 5.2.0). Houston, Texas: Chemstations Inc. Recovered from www.chemstations.com

Chilev, C. \& Simeonov, E. (2014). Simulation of Biodiesel Production by Transesterification of Vegetable Oils. Journal of Chemical Technology and Metallurgy, 49(5), 479-486.

Dimian, A. \& Bildea, C. (2008). Chemical Process Design: Computer-Aided Case Studies. Weinheim: WILEY-VCH Verlag GmbH \& Co. KGaA.

Diwekar, U. (2005). Green Process Design, Industrial Ecology, and Sustainability: a Systems Analysis Perspective. Resources, Conservation and Recycling, 44, 215-235, doi:10.1016/j.resconrec.2005.01.007.

Eliasson, J. (2010). Design of an Plant for Manufacturing of Acetaldehyde. Sweden: Department of Chemical Engineering, Lund University.

Forero, F. Pulido, A. y Cabrera, S. (2016). Modelación y simulación computacional del proceso de evaporación osmótica. Revista Tecnura, 20(49), 29-44, doi: 10.14483/udistrital.jour.tecnura.2016.3.a02.

Johansen, T., Johnsen, A. \& Christiansen, I. (2013). A Comparison of Training Simulators for the Formox Process. Norway: Norwegian University of Science, Faculty of Natural Sciences and Technology. Department of Chemical Engineering and Technology.

Moneti, M., Delfanti, L., Marucci, A. \& Bedini, R. (2015). Simulations of a Plant with a Fluidized Bed Gasifier WGS and PSA. Contemporary Engineering Sciences, 8(31), 1461-1473, doi: http://dx.doi. org/10.12988/ces.2015.56191.

Otte, D., Lorenz, H.-M., \& Repke, J.-U. (2016). A Toolbox Using the Stochastic Optimization Algorithm MIPT and Chemcad for the Systematic Process Retrofit of Complex Chemical Processes. Computers and Chemical Engineering, 84, 371-381, doi: http:// dx.doi.org/10.1016/j.compchemeng.2015.08.023 
Sarwar, A. (2012). Plant Design for the Separation of Various Components from Turpentine Oil. (Master of Science Thesis). Göteborg, Sweden: Chalmers University of Technology.

Snyder, J. \& Subramaniam, B. (1994). A Novel Reverse Flow Strategy for Ethylbenzene Dehydrogenation in a Packed-Bed Reactor. Chem. Eng. Sci., 49, 5585-5601.
Speight, J. (2002). Chemical and Process Design Handbook. New York: The McGraw-Hill Companies, Inc. Towler, G. \& Sinnott, R. (2008). Chemical Engineering Design: Principles, Practice and EConomics of Plant and Process Design. London: Butterworth-Heinemann.

WVU. (2010). ChE 455-Styrene Production. Recovered from http://www.che.cemr.wvu.edu/publications/ projects 